\title{
BOOK TAX DIFFERENCE DAN STRUKTUR KEPEMILIKAN SEBAGAI UPAYA PENGHINDARAN PAJAK
}

\author{
Oleh: \\ Anissa Windarti ${ }^{1}$ \\ Ibnu Sina ${ }^{2}$ \\ Universitas Islam Negeri Syarif Hidayatullah ${ }^{1}$ \\ Universitas Pamulang ${ }^{2}$ \\ Email: \\ anissa.windarti@uinjkt.ac.id ${ }^{1}$
}

\begin{abstract}
ABSTRAK
Rendahnya tingkat kepatuhan Wajib Pajak merupakan masalah besar di Indonesia. Banyak perusahaan melakukan aktivitas penghindaran pajak yang menyebabkan perbedaan jumlah laba akuntansi dengan laba fiskal atau disebut Book Tax Difference (BTD). Penelitian ini bertujuan untuk menganalisis bagaimana pengaruh BTD terhadap penghindaran pajak dengan struktur kepemilikan sebagai variabel pemoderasi. Penelitian ini merupakan penelitian kuantitatif. Populasi yang digunakan adalah seluruh perusahaan yang terdaftar pada Bursa Efek Indonesia. Sampel dalam penelitian ini adalah perusahaan manufaktur yang menerbitkan laporan keuangannya selama periode 2013-2014. Terdapat 122 perusahaan yang terdiri atas 64 perusahaan non-keluarga dan 180 perusahaan keluarga. Teknik pengambilan sampel dengan menggunakan purposive sampling. Untuk menguji hipotesis 1 sampai 3 menggunakan metode pooled regression dengan uji Chow. Hasil penelitian menunjukkan bahwa variabel BTD berpengaruh terhadap penghindaran pajak baik pada perusahaan keluarga maupun non-keluarga. Tetapi penelitian ini tidak berhasil membuktikan secara empirik tentang perbedaan pengaruh BTD terhadap penghindaran pajak antara perusahaan keluarga dan non-keluarga.
\end{abstract}

Kata kunci : Book Tax Difference, penghindaran pajak, struktur kepemilikan

\section{A. PENDAHULUAN}

Reformasi pajak atau tax reform telah terjadi secara bertahap di Indonesia sejak tahun 1983. Reformasi pajak yang terakhir terjadi pada tahun 2002-2009 yang merupakan reformasi kelima kalinya di Indonesia. Penyederhanaan aturan dalam KUP (Ketentuan Umum dan Tatacara Perpajakan) merupakan salah satu tujuan darireformasi pajak. Dengan adanya penyederhanaan ini diharapkan akan memberikan stimulus bagi peningkatan penerimaan pajak.

Upaya penghindaran pajak yang dilakukan oleh perusahaan merupakan sebuah fenomena dari teori keagenan(Monks \& Minow, 2004). Pada teori keagenan menyebutkan bahwa adanya penugasan dari pemberi hak, dalam hal ini pemilik perusahaan, kepada manajemen memunculkan konflik(Monks \& Minow, 
2004). Dalam upaya inilah seorang individu bisa saja melaporkan apa yang telah dicapainya tidak sesuai dengan keadaan yang sebenarnya. Adanya asimetri informasi inilah merupakan suatu wujud konflik yang muncul antara pemilik perusahaan (prinsipal) dan manajemen (agen).

Dalam penelitian Blaylock, menyebutkan bahwa BTD disebabkan oleh tiga faktor yaitu manajemen laba, strategi perencanaan pajak dan perbedaan normal karena adanya perbedaan perlakuan pengakuan beban dan pendapatan menurut akuntansi dan pajak (Blaylock, Shevlin, \& Wilson, 2012). Dari ketiga faktor tersebut, perbedaan normal dapat dijadikan alat untuk memprediksi terjadinya penghindaran pajak. Sedangkan faktor manajemen laba dan perencanaan pajak lebih mengarah ke tindakan oportunistik perusahaan sehingga menimbulkan asimetri informasi laporan keuangan.

Berdasarkan latar belakang masalah di atas, maka tujuan dalam penelitian ini adalah untuk menganalisis pengaruh Book Tax Different (BTD) terhadap penghindaran pajakdengan struktur kepemilikan sebagai variabel pemoderasi.

Penelitian ini diharapkan memberikan manfaat pada pengembangan ilmu pengetahuan di bidang penelitian teori keagenan yaitu pengaruh efek BTD kepemilikan saham keluarga pada penghindaran pajak. Selain itu, penelitian ini memberikan pandangan bagi Direktorat Jenderal Pajak (DJP) bahwa perbedaan laba akuntansi dan laba pajak dapat dijadikan tanda bahwa perusahaan melakukan penghindaran pajak, sehingga dapat dijadikan sebagai alat untuk mengukur kepatuhan wajib pajak. Bagi Otoritas Jasa Keuangan, penelitian ini dapat dijadikan deteksi awal atas perusahaan yang memiliki potensi terjadinya penghindaran pajak.

\section{B. KAJIAN PUSTAKA}

Penelitian tentang pengaruh BTD terhadap persistensi laba sudah sangat sering dilakukan, tetapi studi tentang pengaruh BTD terhadaptax avoidance atau penghindaran pajak masih belum banyak dilakukan di Indonesia dengan hasil yang konsisten. Hasil penelitian Firman menunjukkan bahwa BTD berpengaruh positif terhadap persistensi laba, tetapi interaksi antara BTD dengan kepemilikan institusi tidak memberikan pengaruh terhadap hubungan antara BTD dengan persistensi laba (Firman, 2013). Hasil penelitian Oktavia dan Martani menunjukkan bahwa penghindaran pajak merupakan hasil dari penggunaan derivatif yang ditunjukkan oleh net fair value of derivative (Oktavia \& Martani, 2013).

Berbeda dengan hasil penelitian Pramitasari yang menunjukkan bahwa BTD baik positif maupun negatif tidak berpengaruh terhadap rendahnya persistensi laba (Pramitasari, 2009). Informasi yang terkandung dalam BTD tidak dapat digunakan untuk mengukur besarnya laba masa depan dan tidak bisa digunakan sebagai ukuran untuk menilai kualitas laba. Hal ini menunjukkan bahwa belum ada konsistensi hasil penelitian tentang BTD yang telah dilakukan sebelumnya.

\section{Teori Keagenan}

Dalam hubungan antara pihak pemberi dan penerima hak dan kewajiban berawal dari sebuah kesepakatan atau kontrak. Kontrak inilah yang akan mengikat 
pemberi (principal) dan penerima (agent) sehingga memunculkan tugas dan kewajiban yang harus dilaksanakan. Seperti yang disebutkan oleh Monks dan Minow bahwa teori agensi ini muncul ketika individu memberikan penugasan kepada individu yang lain untuk melakukan suatu jasa tertentu (Monks \& Minow, 2004). Prinsipal menginginkan standar tertentu dalam pencapaian tugas yang diberikan kepada agen, sedangkan agen juga berharap memperoleh hasil yang memuaskan sehingga dia akan mendapat imbalan yang besar. Dalam upaya inilah seorang individu bisa saja melaporkan apa yang telah dicapainya tidak sesuai dengan keadaan yang sebenarnya. Asimetri informasi merupakan salah satu bentuk konflik kepentingan yang muncul dalam hubungan antara prinsipal dan agen.

Kontrak perjanjian antara prinsipal dan agen menjadi salah satu cara untuk meminimalisir konflik kepentingan ini. Menurut Hart, hubungan keagenan mengandalkan kontrak sebagai solusi utama, baik kontrak secara eksplisit maupun implisit (Hart, 1995). Terdapat dua bentuk konflik keagenan berdasarkan distribusi kekuatan prinsipal dalam mempengaruhi keputusan agen. Seperti yang disebutkan Shleifer dan Vishny dalam Sutaryo dan Jakawinarna, yaitu jika distribusi kekuatan prinsipal terdispersi maka organisasi akan mempunyai frekuensi prinsipal yang tinggi dengan kekuatan individual yang kecil (Jakawinarna \& Sutaryo, 2013). Sebaliknya, jika kekuatan terkonsentrasi pada satu atau kelompok prinsipal yang dominan, maka masalah keagenan akanberbentuk konflik antara prinsipal yang mempunyai kekuatan mayoritas dengan kelompok minoritas.

\section{Book Tax Difference}

Penghindaran diri dari pajak (tax avoidance) biasanya dilakukan oleh perusahaan untuk mendapatkan beban pajak yang kecil. Untuk mengecilkan objek pajak, salah satu cara yang dilakukan adalah dengan merekayasa beban atau pengeluaran perusahaan. Berdasarkan pasal 6 Undang-Undang Pajak Penghasilan, untuk menghitung besarnya Penghasilan Kena Pajak bagi Wajib Pajak Dalam Negeri dan bentuk usaha tetap ditentukan berdasarkan penghasilan bruto dikurangi biaya untuk mendapatkan, menagih dan memelihara penghasilan.

BTD merupakan perbedaan laba berbasis nilai buku dengan laba pajak. Menurut Blaylock etal (Blaylock, Shevlin, \& Wilson, 2012), BTD terjadi karena tiga kegiatan manajemen laba, manajemen pajak dan perbedaan ketentuan akuntansi serta perpajakan (normal BTD). Sedangkan Tang dan Firth (Tang \& Firth, 2012)menyebutkan sumber BTD ada dua macam yaitu BTD yang berasal dari perbedaan laba akuntansi dan laba pajak (normal BTD) dan BTD yang berasal dari aktivitas manajemen laba dan manajemen pajak (abnormal BTD).Menurut Bambang Kesit (Resmi, 2009), untuk menjembatani perbedaan laba akuntansi dan laba pajak, perusahaan perlu membuat laporan keuangan fiskal ekstrakomtabel dengan laporan keuangan bisnis. Perusahaan menyusun laporan keuangan fiskal melalui penyesuaian atau proses rekonsiliasi.

Banyak penelitian yang telah menguji faktor-faktor pembentuk BTD. Hasil penelitian Sismi dan Martani (Sismi \& Martani., 2014)menunjukkan bahwa BTD dipengaruhi oleh variabel pajak, kepemilikan keluarga pre-tax book income yang negatif (LOSS) serta utilisasi kerugian pajak (TLU). Hasil penelitian Fontanella 
dan Martani (Fontanella \& Martani, 2014)memberikan bukti empiris bahwa karakteristik perusahaan berupa ukuran perusahaan, profitabilitas dan kualitas laba berpengaruh tehadap BTD. Akan tetapi karakteristik perusahaan berupa leverage dan likuiditas tidak terbukti berpengaruh pada BTD.

Penelitian Sirait dan Martani (Sirait \& Martani, 2014)menggunakan proksi BTD untuk mendeteksi penghindaran pajak. Hasil penelitian menunjukkan bahwa kepemilikan keluarga berpengaruh pada penghindaran pajak. Secara empiris, perusahaan keluarga lebih menghindari pajak daripada perusahaan non-keluarga. Dalam penelitian ini juga menemukan fakta bahwa perusahaan keluarga di Malaysia lebih menghindari pajak dibandingkan perusahaan keluarga di Indonesia.

\section{Struktur Kepemilikan}

Struktur kepemilikan terdiri atas dua macam, yaitu struktur kepemilikan tersebar dan struktur kepemilikan terkonsentrasi(Yuniasih, 2013). Struktur kepemilikan tersebar terjadi apabila outsider equity dimiliki oleh banyakinvestor dan setiap investor memiliki nilai ekuitas yang relatif kecil. Akan tetapi, padastruktur kepemilikan terkonsentrasi, sebagian besar saham dimiliki oleh sebagian kecilindividu atau kelompok, sehingga individu atau kelompok tersebut memiliki jumlah sahamrelatif dominan dibandingkan dengan pemegang saham lainnya. Pemegang saham mayoritasdapat meningkatkan kepemilikannya melalui struktur kepemilikan secara piramida,kepemilikan silang dan melalui keterlibatan pemegang saham mayoritas dalam perusahaan.

Hasil penelitian Sirait dan Martani (Sirait \& Martani, 2014) menunjukkan bahwa kepemilikan keluarga berpengaruh positif terhadap penghindaran pajak. Dalam penelitian tersebut, stuktur kepemilikan dibedakan menjadi kepemilikan keluarga dan non keluarga. Dari penelitian Nuritomo dan Martani (Nuritomo \& Martani, 2014) ditemukan adanya hasil penelitian yang berbeda. Kepemilikan keluarga tidak berpengaruh terhadap kecenderungan perusahaan untuk mengajukan insentif pajak.

Penghindaran pajak dapat berdampak pada reputasi perusahaan keluarga yang akan menjadi beban untuk jangka panjang (Nuritomo \& Martani, 2014). Hal ini disebabkan karena perusahaan keluarga memiliki investasi jangka panjang dan sangat berharap adanya kelangsungan usaha. Adanya denda serta sanksi akan mendorong perusahaan keluarga untuk menghindari manajemen laba dan tax avoidance. Bukti empiris dalam penelitian Chen et.al (2010) menunjukkan bahwa kepemilikan keluarga akan mengurangi adanya penghindaran pajak. Namun fakta yang berbeda ditemukan pada hasil penelitian Sari (Sari, 2013) yang menunjukkan bahwa kepemilikan keluarga cenderung lebih agresif untuk melakukan penghindaran pajak.

\section{Kerangka Berpikir}

Berdasarkan tinjauan literatur di atas, maka dibuat kerangka konseptual pada gambar di bawah ini. 


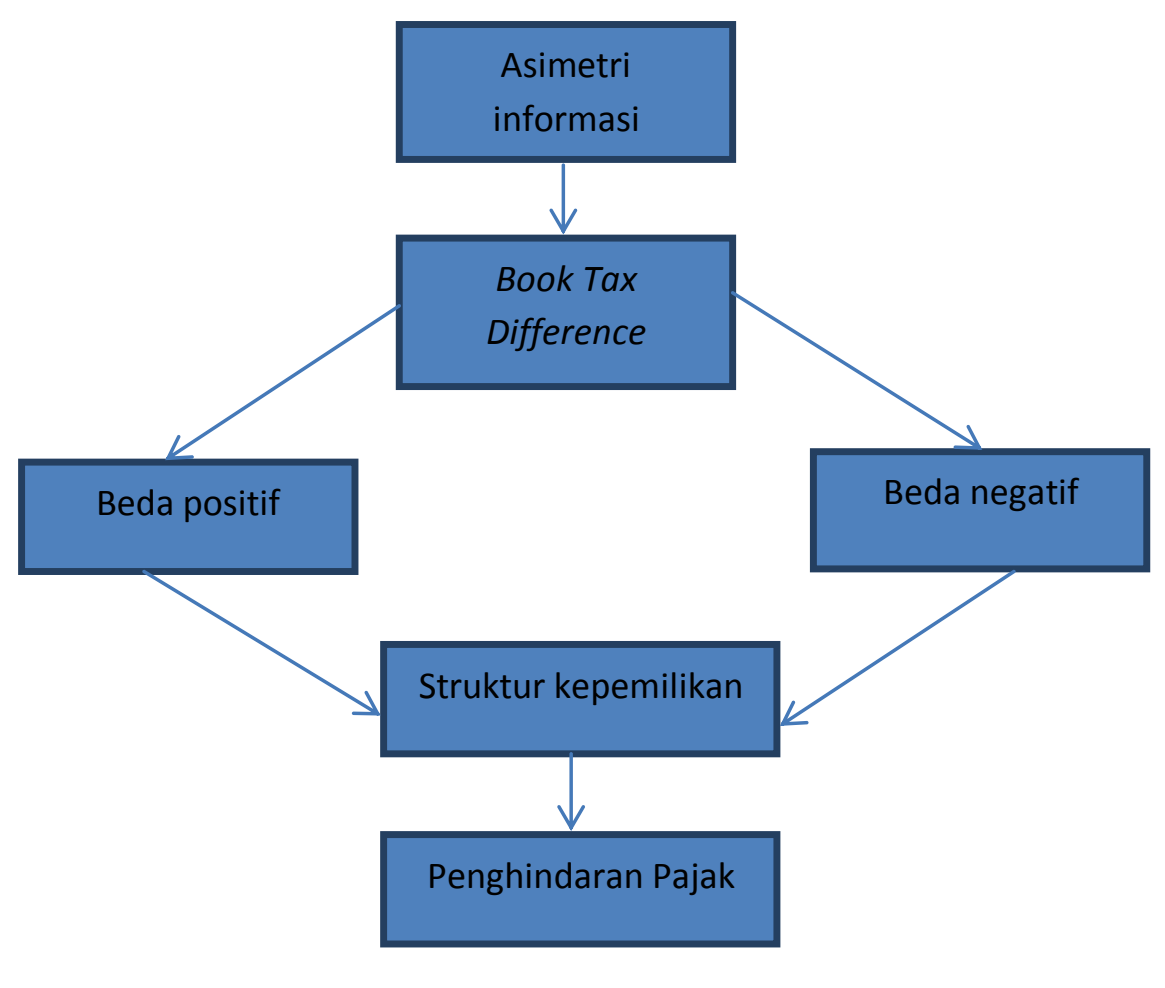

Sumber: Diolah Peneliti

Gambar 1.

Kerangka Berpikir

\section{Hipotesis Penelitian}

Hipotesis yang diajukan dalam penelitian ini adalah

H1a : terdapat pengaruh BTD terhadap penghindaran pajak pada perusahaan non-keluarga

$\mathrm{H} 2 \mathrm{a}$ : terdapat pengaruh BTD terhadap penghindaran pajak pada perusahaan keluarga

H3a: terdapat perbedaanpengaruh BTD terhadap penghindaran pajakantara perusahaan keluarga dan non-keluarga

\section{METODE PENELITIAN}

Penelitian ini dilaksanakan dari bulan Juni sampai Oktober 2016. Data penelitian diperoleh dari data sekunder berupa laporan keuangan perusahaanperusahaan yang terdaftar di Bursa Efek Indonesia untuk periode 2013-2014 yang dapat diakses dari www.idx.co.id maupun website resmi perusahaan.Penelitian ini merupakan jenis penelitian kuantitatif dengan menggunakan data sekunder berupa laporan keuangan perusahaan manufaktur yang terdaftar di Bursa Efek Indonesia dari tahun 2013-2014.

Populasi yang digunakan adalah seluruh perusahaan yang terdaftar di Bursa Efek Indonesia pada tahun 2013-2014. Sampel dalam penelitian ini adalah perusahaan manufaktur yang menerbitkan laporan keuangannya selama periode 
2013-2014. Teknik pengambilan sampel dengan menggunakan purposive sampling. Peneliti akan mengambil sampel dengan syarat-syarat atau pertimbangan tertentu. Berikut kriteria-kriteria yang digunakan dalam pemilihan sampel :

1. Perusahaan yang mempublikasikan laporan keuangan tahunan auditan pada tahun 2013-2014.

2. Bukan perusahaan yang bidang usahanya bergerak pada sektor keuangan, perhotelan, travel, transportasi dan real estate. Sektor-sektor tersebut memiliki struktur kekayaan (aset) yang unik terutama pada struktur aset tetap sehingga akan mengaburkan penilaian.

3. Kepemilikan saham perusahaan bukan dimiliki oleh negara.

Tabel 1.

\section{Rincian Sampel Penelitian}

\begin{tabular}{lc}
\hline \multicolumn{1}{c}{ DESKRIPSI } & JUMLAH \\
\hline Perusahaan manufaktur yang terdaftar di BEI tahun 2013-2014 & 141 \\
Perusahaan yang melakukan IPO di tahun 2014 & -3 \\
Perusahaan dengan data yang tidak lengkap & -17 \\
Perusahaan milik Negara & -5 \\
Jumlah sampel & 122 \\
Periode laporan keuangan (2 tahun) & 244 \\
\hline
\end{tabular}

Teknik pengumpulan data dalam penelitian adalah dengan observasi data sekunder berupa laporan keuangan. Laporan keuangan diamati untuk kemudian dicatat beberapa hal penting sesuai dengan proksi untuk masing-masing variabel. Data laporan keuangan diperoleh dari Bursa Efek Indonesia dan website perusahaan.

Untuk menguji hipotesis menggunakan model pooled regressionyang menggunakan data metrik dan non-metrik bagi variabel independen serta data metrik untuk variabel dependen. Data untuk variabel $\mathrm{X}_{2}$ merupakan data nonmetrik karena menggunakan variabel dummy yaitu perusahaan keluarga (kode 1) dan perusahaan non-keluarga (kode 0). Terdapat tiga kemungkinan model regresi antara variabel $\mathrm{X}_{1}, \mathrm{X}_{2}$ dan $\mathrm{Y}$ adalah sebagai berikut:

$\begin{array}{lll}\text { Perusahaan non-keluarga } Y_{t}=\lambda_{1}+\lambda_{2} X t+u_{1 t} & n_{1}=64 \ldots \ldots \text { (i) } \\ \text { Perusahaan keluarga } & Y_{t}=\mathbb{V} 1+\not y 2 X t+u_{2 t} & n_{2}=180 \ldots . .(i i) \\ \text { Seluruh perusahaan } & Y_{t}=\alpha_{1}+\alpha_{2} X t+u_{t} & n=\left(n_{1}+n_{2}\right)=244\end{array}$

Model regresi ketiga mengasumsikan bahwa tidak ada perbedaan di antara perusahaan non-keluarga dan perusahaan keluarga sehingga estimasi hubungan antara BTD dan penghindaran pajak untuk seluruh perusahaan yang diobservasi. Menurut Gujarati (Gujarati \& Porter, 2013)regresi ini mengasumsikan bahwa intercept seperti halnya koefisien kemiringan tetap sama sepanjang waktu, yang berarti tidak ada perubahan struktural. Maka situasinya $\alpha_{1}=\lambda_{1}=\mathbb{V}_{1}$ atau $\alpha_{2}=\lambda_{2}=$ $\mathbb{V} 2$ 
Variabel Y dalam penelitian ini diproksikan dengan GAAP ETR, sedangkan variabel X diproksikan dengan BTD. Model dasar pengujian penghindaran pajak yang dilakukan dalam penelitian ini adalah sebagai berikut :

$\begin{array}{lll}\text { FAM (dummy 0) } & \text { GAAP ETR }_{\mathrm{it}}=\lambda_{1}+\lambda_{2} \mathrm{BTD}_{\mathrm{it}}+\mathrm{u}_{\mathrm{ut}} & \mathrm{n}_{1}=64 \\ \text { FAM (dummy 1) } & \text { GAAP ETR }_{\mathrm{it}}=\mathbb{V}_{1}+\not{ }_{2} \mathrm{BTD}_{\mathrm{it}}+\mathrm{u}_{2 \mathrm{t}} & \mathrm{n}_{2}=180 \\ \text { FAM } & \text { GAAP ETR }_{\mathrm{it}}=\alpha_{1}+\alpha_{2} \text { BTD }_{\mathrm{it}}+\mathrm{u}_{\mathrm{t}} & \mathrm{n}=\left(\mathrm{n}_{1+}+\mathrm{n}_{2}\right)=244\end{array}$

Keterangan :

GAAP ETR $\mathrm{ET}_{\mathrm{it}}=$ Effective Tax Rate untuk perusahaan i pada tahun ke $\mathrm{t}$

$\mathrm{BTD}_{\mathrm{it}}=$ Book Tax Differences untuk perusahaan i pada tahun ke $\mathrm{t}$

$\mathrm{FAM}_{\mathrm{it}}=$ struktur kepemilikan saham perusahaan i pada tahun ke $\mathrm{t}$, dummy variabel (1) untuk perusahaan keluarga, (0) untuk perusahaannon-keluarga

Pengujian hipotesis penelitian dengan menggunakan uji Chow (Gujarati \& Porter, 2013)

Definisi Operasional Variabel

1) Variabel Dependen

Variabel dependen dalam penelitian ini adalah penghindaran pajak yang diproksikan dengan GAAP ETR, mengacu pada penelitian Pradipta dan Supriyadi (Pradipta \& Surpiyadi, 2015)serta Nuritomo dan Martani (Nuritomo \& Martani, 2014). Penggunaan proksi GAAP ETR dinilai lebih mencerminkan dampak dari beda temporer jika dibandingkan dengan Current ETR. GAAP ETR dihitung dengan rumus sebagai berikut :

2) Variabel Independen

$$
\text { GAAPETR }=\frac{\text { total beban pajak }}{\text { laba sebelum pajak }}
$$

Variabel independen dalam penelitian ini adalah BTD yaitu berupa perbedaan laba berbasis nilai buku dan nilai pajak, mengacu pada penelitian Tang dan Firth (Tang \& Firth, 2012), Fontanella dan Martani (Fontanella \& Martani, 2014), Rusydi dan Martani (Rusydi \& Martani., 2014) serta Sismi dan Martani (Sismi \& Martani., 2014). BTD dihitung dengan rumus sebagai berikut:

$$
\begin{gathered}
B T D=\frac{\text { (laba akuntansi - laba pajak) }}{\text { total aset }} \\
\text { laba pajak }=\frac{\text { beban pajak kini }}{\text { tarif pajak }}
\end{gathered}
$$

3) Variabel Pemoderasi

Variabel pemoderasi dalam penelitian ini adalah struktur kepemilikan, dengan menggunakan variabel dummy, yaitu nilai 1 untuk perusahaan keluarga dan nilai 0 untuk kepemilikan non keluarga. Penggunaan variabel dummy ini mengacu pada penelitian Nuritomo dan Martani yang mensyaratkan persentase kepemilikan sebesar $20 \%$ suatu perusahaan dianggap sebagai perusahaan keluarga(Nuritomo \& Martani, 2014). 


\section{HASIL DAN PEMBAHASAN}

Perusahaan di Indonesia didominasi oleh perusahaan keluarga. Dari 244 sampel perusahaan manufaktur, terdapat 180 perusahaan keluarga atau sebanyak $73,77 \%$. Hal ini menunjukkan besarnya investasi untuk publik tidak terlalu banyak. Struktur kepemilikan saham dikuasai oleh keluarga, maupun korporasi berupa holding company.

Jika melihat besarnya mean BTD pada perusahaan non-keluarga yaitu 0,1368 dibandingkan dengan mean perusahaan keluarga yaitu $-5,4848$ maka dapat disimpulkan bahwa perbedaan nilai laba akuntansi dengan laba fiskal lebih besar terjadi pada perusahaan non-keluarga. Hal ini menunjukkan bahwa perusahaan keluarga akan lebih berhati-hati dalam merencanakan pajak untuk menghindari sanksi pajak jika terbukti kurang bayar.

Nilai GAAP ETR menggambarkan tindakan penghindaran pajak pada perusahaan. Pada perusahaan keluarga mean GAAP ETR sebesar -2,5 yang jauh lebih kecil jika dibandingkan dengan perusahaan non-keluarga. Nilai GAAP ETR pada perusahaan non-keluarga adalah sebesar -0,1817. Artinya perusahaan keluarga cenderung untuk mengurangi praktik penghindaran pajak dibandingkan dengan perusahaan non-keluarga.

Model regresi untuk perusahaan non-keluarga adalah sebagai berikut:

$$
\mathrm{Y}_{\mathrm{t}}=\lambda_{1}+\lambda_{2} \mathrm{Xt}+\mathrm{u}_{1 \mathrm{t}} \quad \mathrm{n}_{1}=64
$$

Besarnya Restricted residual sum of squares atau RSS1 adalah 6,291 dan besarnya $\mathrm{R}^{2}$ adalah 0,155 . Nilai $\mathrm{df}=64-2=62$. Persamaan (i) dapat dituliskan sebagai berikut

$$
\begin{aligned}
& Y_{t}=-0,116+(-0,483) X t \\
& t=(-2,613) \quad(-3,378)
\end{aligned}
$$

Berdasarkan tabel di atas ditampilkan besarnya adjusted $\mathrm{R}^{2}$ adalah 0,142 , hal ini berarti $14,2 \%$ variasi penghindaran pajak dapat dijelaskan oleh variasi dari variabel BTD untuk perusahaan non-keluarga. Hasil uji $\mathrm{F}$ pada tabel 4.6 nilai $\mathrm{F}$ sebesar 11,411 dengan probabilitas 0,000. Karena probabilitas jauh lebih kecil dari 0,05 maka dapat disimpulkan bahwa BTD berpengaruh terhadap penghindaran pajak pada perusahaan non-keluarga. Dengan demikian hipotesis pertama pada penelitian ini diterima.

Tabel 2.

Nilai R Square untuk Perusahaan Non-Keluarga

\begin{tabular}{|l|c|r|c|c|}
\hline Model & R & R Square & $\begin{array}{c}\text { Adjusted R } \\
\text { Square }\end{array}$ & $\begin{array}{c}\text { Std. Error of the } \\
\text { Estimate }\end{array}$ \\
\hline 1 & $.394^{\mathrm{a}}$ & .155 & .142 & .31854 \\
\hline a. Predictors: (Constant), VAR00004 & \\
b. Dependent Variable: VAR00005
\end{tabular}


Tabel 3.

Nilai Residual Sum of Square untuk Perusahaan Non-Keluarga

\begin{tabular}{|c|c|c|c|c|c|c|}
\hline \multicolumn{7}{|c|}{ ANOVA $^{b}$} \\
\hline & & Sum of Squares & $\mathrm{Df}$ & Mean Square & $\mathrm{F}$ & Sig. \\
\hline \multirow[t]{3}{*}{1} & Regression & 1.158 & 1 & 1.158 & 11.411 & $.001^{a}$ \\
\hline & Residual & 6.291 & 62 & |101 & & \\
\hline & Total & 7.449 & 63 & & & \\
\hline
\end{tabular}

a. Predictors: (Constant), VAR00004

b. Dependent Variable: VAR00005

Tabel 4.

Nilai Beta dan t untuk Perusahaan Non-Keluarga

Coefficients $^{\mathrm{a}}$

\begin{tabular}{|c|c|c|c|c|c|c|}
\hline \multirow{2}{*}{\multicolumn{2}{|c|}{ Model }} & \multicolumn{2}{|c|}{$\begin{array}{l}\text { Unstandardized } \\
\text { Coefficients }\end{array}$} & \multirow{2}{*}{$\begin{array}{c}\begin{array}{c}\text { Standardized } \\
\text { Coefficients }\end{array} \\
\text { Beta } \\
\end{array}$} & \multirow[b]{2}{*}{$\mathrm{T}$} & \multirow[b]{2}{*}{ Sig. } \\
\hline & & $\mathrm{B}$ & Std. Error & & & \\
\hline \multirow[t]{2}{*}{1} & (Constant) & -.116 & .044 & & -2.613 & .011 \\
\hline & VAR00004 & -.483 & .143 & -.394 & -3.378 & .001 \\
\hline
\end{tabular}

Model regresi untuk perusahaan keluarga adalah sebagai berikut:

$$
\mathrm{Y}_{\mathrm{t}}=\mathbb{V}{ }_{1}+\mathbb{V}_{2} \mathrm{Xt}+\mathrm{u}_{2 \mathrm{t}} \mathrm{n}_{2}=180
$$

Besarnya Restricted residual sum of squares atau RSS2 adalah 388,264 dan besarnya $R^{2}$ adalah 0,997 . Nilai $\mathrm{df}=180-2=178$. Persamaan (i) dapat dituliskan sebagai berikut

$$
\begin{aligned}
Y_{t} & =-0,154+(-0,484) X t \ldots \\
t & =(-1,392) \quad(-231,370)
\end{aligned}
$$

Berdasarkan tabel 5 ditampilkan besarnya adjusted $\mathrm{R}^{2}$ adalah 0,997 , hal ini berarti 99,7\% variasi penghindaran pajak dapat dijelaskan oleh variasi dari variabel BTD untuk perusahaan keluarga. Hasil uji F pada tabel 4.9 nilai F sebesar 5.353E4dengan probabilitas 0,000. Karena probabilitas jauh lebih kecil dari 0,05 maka dapat disimpulkan bahwa BTD berpengaruh terhadap penghindaran pajak pada perusahaan keluarga. Meskipun secara statistik terbukti signifikan, tetapi nilai $\mathrm{F}$ sangat kecil. Dengan demikian hipotesis kedua pada penelitian ini diterima.

Tabel 5.

Nilai R Square untuk Perusahaan Keluarga Model Summary

\begin{tabular}{l|r|r|r|c|}
\hline Model & $\mathrm{R}$ & $\mathrm{R}$ Square & $\begin{array}{c}\text { Adjusted R } \\
\text { Square }\end{array}$ & $\begin{array}{c}\text { Std. Error of the } \\
\text { Estimate }\end{array}$ \\
\hline 1 & $.998^{\mathrm{a}}$ & .997 & .997 & 1.47691 \\
\hline
\end{tabular}
a. Predictors: (Constant), VAR00006
b. Dependent Variable: VAR00007




\section{Tabel 6}

Nilai Residual Sum of Square untuk Perusahaan Keluarga

\begin{tabular}{ll|r|r|r|r|r|}
\hline Model & & Sum of Squares & df & Mean Square & F & Sig. \\
\hline 1 & Regression & 116767.242 & 1 & 116767.242 & $5.353 \mathrm{E} 4$ & $.000^{\text {a }}$ \\
& Residual & 388.264 & 178 & 2.181 & & \\
Total & 117155.506 & 179 & & & \\
\hline
\end{tabular}
a. Predictors: (Constant), VAR00006
b. Dependent Variable: VAR00007

Tabel 7.

Nilai Beta dan $t$ untuk Perusahaan Keluarga

Coefficients $^{\mathrm{a}}$

\begin{tabular}{|c|c|c|c|c|c|c|}
\hline \multirow{2}{*}{\multicolumn{2}{|c|}{ Model }} & \multicolumn{2}{|c|}{$\begin{array}{l}\text { Unstandardized } \\
\text { Coefficients }\end{array}$} & \multirow{2}{*}{$\begin{array}{c}\begin{array}{c}\text { Standardized } \\
\text { Coefficients }\end{array} \\
\text { Beta }\end{array}$} & \multirow[b]{2}{*}{$t$} & \multirow[b]{2}{*}{ Sig. } \\
\hline & & $B$ & Std. Error & & & \\
\hline \multirow[t]{2}{*}{1} & (Constant) & -.154 & .111 & & -1.392 & .166 \\
\hline & VAR00006 & -.484 & .002 & -.998 & -231.370 & .000 \\
\hline
\end{tabular}

Model regresi ketiga menunjukkan pengaruh BTD terhadap penghindaran pajak pada seluruh perusahaan yang diobservasi. Gabungan perusahaan keluarga dan non-keluarga merupakan penjumlahan dari 64 sampel perusahaan nonkeluarga dan 180 sampel perusahaan keluarga $\left(n_{1}+n_{2}=64+180=244\right)$. Model regresi untuk total perusahaan keluarga dan non-keluarga adalah sebagai berikut:

$$
\mathrm{Y}_{\mathrm{t}}=\alpha_{1}+\alpha_{2} \mathrm{Xt}+\mathrm{u}_{\mathrm{t}} \quad \mathrm{n}=\left(\mathrm{n}_{1}+\mathrm{n}_{2}\right)=244
$$

Besarnya Restricted residual sum of squares atau RSS3 adalah 394.624 dan besarnya $R^{2}$ adalah 0,997 . Nilai $\mathrm{df}=244-2=242$. Persamaan (i) dapat dituliskan sebagai berikut

$$
\begin{aligned}
Y_{t} & =-0,144+(-0,484) X t \ldots \ldots \ldots \ldots . .(\text { iii.a }) \\
t & =(-1.753) \quad(-267.984)
\end{aligned}
$$

Tabel 8.

\begin{tabular}{|c|c|c|c|c|}
\hline Model & $\mathrm{R}$ & R Square & Adjusted R Square & $\begin{array}{l}\text { Std. Error of the } \\
\text { Estimate }\end{array}$ \\
\hline 1 & $.998^{\mathrm{a}}$ & .997 & .997 & 1.27698 \\
\hline
\end{tabular}

Nilai R Square untuk Perusahaan Gabungan

Model Summary ${ }^{\mathrm{D}}$ 
Tabel 9.

Nilai Residual Sum of Square untuk Perusahaan Gabungan ANOVA $^{\mathrm{D}}$

\begin{tabular}{ll|r|r|r|r|r|}
\hline Model & Sum of Squares & df & Mean Square & \multicolumn{1}{c|}{ F } & Sig. \\
\hline 1 & Regression & 117108.087 & 1 & 117108.087 & $7.182 E 4$ & $.000^{\text {a }}$ \\
Residual & 394.624 & 242 & 1.631 & & \\
Total & 117502.711 & 243 & & & \\
\hline
\end{tabular}
a. Predictors: (Constant), VAR00001
b. Dependent Variable: VAR00003

Tabel 10.

Nilai Beta dan $t$ untuk Perusahaan Gabungan

Coefficients $^{a}$

\begin{tabular}{|c|c|c|c|c|c|c|}
\hline \multirow{2}{*}{\multicolumn{2}{|c|}{ Model }} & \multicolumn{2}{|c|}{$\begin{array}{c}\text { Unstandardized } \\
\text { Coefficients }\end{array}$} & \multirow{2}{*}{$\begin{array}{c}\begin{array}{c}\text { Standardized } \\
\text { Coefficients }\end{array} \\
\text { Beta }\end{array}$} & \multirow[b]{2}{*}{$t$} & \multirow[b]{2}{*}{ Sig. } \\
\hline & & B & Std. Error & & & \\
\hline \multirow[t]{2}{*}{1} & (Constant) & -.144 & .082 & & -1.753 & .081 \\
\hline & VAR00001 & -.484 & .002 & -.998 & -267.984 & .000 \\
\hline
\end{tabular}

Oleh karena dua kelompok sampel berdiri sendiri-sendiri atau tidak berhubungan, maka akan diperoleh RSS yang tidak terbatas $\left(\mathrm{RSS}_{\mathrm{UR}}\right)$

$$
\mathrm{RSS}_{\mathrm{UR}}=\mathrm{RSS}_{1}+\mathrm{RSS}_{2} \quad \text { dengan df }=\left(\mathrm{n}_{1}+\mathrm{n}_{2}-2 \mathrm{k}\right)
$$

Pada penelitian ini diperoleh :

$\operatorname{RSS}_{\mathrm{UR}}=(6,291+388,264)=394,555 \quad$ dengan $\mathrm{df}=(64+180-4)=240$

Besarnya rasio $\mathrm{F}$ adalah

$$
F=\frac{(394.624-394,555) / 2}{394,555 / 240}=0,021
$$

Dari tabel $\mathrm{F}$, nilai untuk $\mathrm{df}=2$ dan 240 ditemukan bahwa nilai $\mathrm{F}$ tabel adalah 3,00 pada tingkat signifikansi 95\%. Karena $\mathrm{F}$ hitung lebih kecil dari $\mathrm{F}$ tabel maka hipotesis nol tidak dapat ditolak, sehingga dapat disimpulkan bahwa tidak ada perbedaan pengaruh BTD pada penghindaran pajak antara perusahaan keluarga dan non-keluarga.

Hasil penelitian ini menunjukkan bahwa antara perusahaan keluarga dan non keluarga tidak memiliki perbedaan dalam hal menilai pengaruh BTD dengan penghindaran pajak. Meskipun begitu, hasil analisis model regresi pada perusahaan keluarga, non-keluarga serta gabungan menunjukkan adanya pengaruh yang signifikan BTD terhadap penghindaran pajak. Hal ini memberikan dukungan dari penelitian sebelumnya bahwa BTD mempengaruhi penghindaran pajak tetapi penelitian ini belum bisa membuktikan bahwa struktur kepemilikan mempengaruhi praktik penghindaran pajak.

Hasil regresi pada model BTD dengan penghindaran pajak pada perusahaan keluarga dan non-keluarga menunjukkan pengaruh yang signifikan. Hal ini sesuai dengan pernyataan bahwa adanya perbedaan temporer yang terjadi antara aturan 
dalam akuntansi dan perpajakan merupakan tindakan penghindaran pajak bukan praktik manajemen laba (Cahyadi \& Sumiyana, 2013).

Hasil penelitian ini juga konsisten dengan penelitian Sismi dan Martani (Sismi \& Martani., 2014)yang menunjukkan bahwa perusahaan dengan NBTD positif yang besar tidak terbukti memiliki persistensi laba yang lebih rendah. Pada komponen ABTD terbukti bahwa perusahaan melakukan aktivitas manajemen laba dan manajemen pajak memiliki persistensi laba lebih rendah. Sedangkan struktur kepemilikan keluarga menjadi kurang informatif dibandingkan dengan informasi perpajakan, sehingga menyebabkan kurangnya pengaruh kepemilikan keluarga terhadap penghindaran pajak.

Keterbatasan informasi dalam pemegang saham yang didominasi oleh keluarga bisa saja disebabkan sikap ekspropriasi yang berlebihan dalam perusahaan (La Porta dalam Sismi dan Martani (Sismi \& Martani., 2014). Bisa saja dalam hal penempatan anggota keluarga yang kurang memiliki kapabilitas dalam perusahaan menjadi penyebab keterbatasan informasi. Dengan adanya keterbatasan informasi pada anggota keluarga menyebabkan kurangnya keterlibatan mereka dalam menentukan kebijakan untuk penghindaran pajak.

Faktor yang lain seperti pembayaran kepada pihak eksekutif yang berlebihan juga menyebabkan kurangnya perhatian pemilik perusahaan atas beban pajak yang dibayarkan oleh perusahaan. Honor ataupun penghasilan yang diberikan kepada pemegang saham merupakan jenis deductible expense sehingga akan mengurangi laba perpajakan tetapi akan menjadi pengeluaran yang besar bagi perusahaan. Praktik manajemen laba seperti ini hanya akan memberikan manfaat jangka pendek bagi perusahaan, dan akan merugikan untuk jangka panjang.

Hipotesis yang menyebutkan bahwa terdapat perbedaan pengaruh BTD terhadap penghindaran pajak antara perusahaan keluarga dan non-keluarga tidak dapat dibuktikan secara empiris dalam penelitian ini. Hasil ini tidak konsisten dengan hasil penelitian Sirait dan Martani yang menunjukkan adanya kepemilikan keluarga berpengaruh positif terhadap penghindaran pajak di Indonesia (Sirait \& Martani, 2014). Namun hasil yang berbeda ditemukan pada perusahaanperusahaan di Malaysia. Kepemilikan perusahaan tidak mempengaruhi penghindaran pajak di Malaysia.

Beberapa keterbatasan yang harus dicermati dalam menginterpretasikan hasil penelitian ini antara lain :

1. Rentang waktu pengambilan sampel hanya dibatasi pada tahun 2013-2014 saja dan pada industri manufaktur. Hal ini disebabkan karena keterbatasan waktu penelitian dan biaya. Penggunaan data tahun 2013 dan keterbatasan pada industri manufaktur dikhawatirkan tidak dapat menggambarkan kondisi yang sebenarnya pada seluruh perusahaan publik.

2. Penelusuran BTD tidak dilakukan dengan membagi BTD menjadi beda positif dan beda negatif seperti pada penelitian Cahyadi dan Sumiyana (2013) atau membedakan BTD dengan Large Possitive NBTD dan Large Negative NBTD seperti pada penelitian Tang dan Firth (2012) serta penelitian Sismi dan Martani (2013). Dengan menggunakan nilai NBTD merupakan BTD dengan karakteristik normal yaitu timbul karena 
perbedaan ketentuan akuntansi dan perpajakan, bukan sebagai tindakan manajemen laba atau manajemen pajak.

3. Pembagian struktur kepemilikan supaya memperhatikan kepemilikan asing, negara maupun holding company sehingga akan lebih memperjelas keterlibatan pemilik dalam penghindaran pajak.

\section{E. SIMPULAN}

Berdasarkan pembahasan hasil penelitian, maka dapat disimpulkan bahwa BTD berpengaruh terhadap penghindaran pajak. Hal ini terjadi baik pada perusahaan keluarga, non-keluarga ataupun keduanya. Besarnya adjusted $\mathrm{R}^{2}$ adalah 0,142 , hal ini berarti $14,2 \%$ variasi penghindaran pajak dapat dijelaskan oleh variasi dari variabel BTD untuk perusahaan non-keluarga. Hasil uji F menunjukkan nilai $\mathrm{F}$ sebesar 11,411 dengan probabilitas 0,000 yang menunjukkan signifikan pada tingkat kepercayaan $95 \%$.

Hipotesis kedua dalam penelitian ini dapat dibuktikan secara empirik dengan diperolehnya hasil adjusted $\mathrm{R}^{2}$ adalah 0,997 , hal ini berarti 99,7\% variasi penghindaran pajak dapat dijelaskan oleh variasi dari variabel BTD untuk perusahaan keluarga. Hasil uji $\mathrm{F}$ pada tabel 4.9 nilai $\mathrm{F}$ sebesar 5.353E4 dengan probabilitas 0,000 yang artinya signifikan pada tingkat kepercayaan $95 \%$.

Hipotesis ketiga tentang adanya perbedaan pengaruh BTD terhadap penghindaran pajak pada perusahaan keluarga dan non-keluarga tidak dapat dibuktikan secara empirik. Hal ini ditunjukkan oleh nilai $\mathrm{F}$ hitung $0,021<$ dari $\mathrm{F}$ tabel 3,00 untuk df $=2$ dan 240 pada tingkat signifikansi 95\%. Faktor yang menyebabkan kondisi ini mungkin adanya tindakan ekspropriasi yang rawan terjadi pada perusahaan keluarga. Faktor yang lain bisa jadi karena rendahnya tingkat kepatuhan wajib pajak di Indonesia, serta keterbatasan informasi pajak yang diterima oleh pemilik keluarga, misalnya tentang penurunan tarif pajak bagi wajib pajak badan.

Penelitian ini memberikan implikasi pada pengembangan ilmu pengetahuan di bidang penelitian teori keagenan yaitu pengaruh efek kepemilikan saham keluarga pada penghindaran pajak. Hasil penelitian ini juga memberikan pandangan bahwa perbedaan laba akuntansi dan laba pajak dari karakteristik normal akan memberi pengaruh pada penghindaran pajak.

Penelitian ini memberikan pandangan bagi Direktorat Jenderal Pajak (DJP) bahwa perbedaan laba akuntansi dan laba pajak dapat dijadikan tanda bahwa perusahaan melakukan penghindaran pajak, sehingga dapat dijadikan sebagai alat untuk mengukur kepatuhan wajib pajak. Bagi Otoritas Jasa Keuangan, penelitian ini dapat dijadikan deteksi awal atas perusahaan yang memiliki potensi terjadinya penghindaran pajak.

Berdasarkan keterbatasan penelitian ini, maka ada beberapa rekomendasi yang penting untuk dilakukan pada penelitian mendatang berkaitan dengan BTD.

1. Rentang waktu penelitian bisa lebih diperpanjang tidak hanya 2 tahun sehingga lebih bisa menggambarkan kondisi perusahaan yang sebenarnya. Demikian pula pengambilan sampel agar diperluas lagi tidak hanya meliputi perusahaan manufaktur saja tetapi keseluruhan perusahaan yang terdaftar di BEI. 
2. Penelusuran BTD agar menggunakan dua karakteristik yaitu karakteristik normal yang mencerminkan penghindaran pajak serta karakteristik oportunis yang mendeteksi tindakan manajemen laba dan manajemen pajak secara agresif. Besarnya BTD juga perlu diperhatikan jenisnya, seperti beda postif dan beda negatif.

\section{DAFTAR PUSTAKA}

Abdillah, W., \& Jogiyanto. (2015). Partial Least Square (PLS) Alternatif Structural Equation Modelling (SEM) dalam Penelitian Bisnis. Yogyakarta: Penerbit Andi.

Arieftiara, D., Utama, S., Wardhani, R., \& Rahayu, N. (2015). Analisis Pengaruh Strategi Bisnis terhadap Penghindaran Pajak, Bukti Empiris di Indonesia. Simposium Nasional Akuntansi 18. Medan.

Blaylock, B., Shevlin, T., \& Wilson, R. J. (2012). Tax Avoidance, Large Positive Temporary Book-Tax Differences, and Earnings Persistence. The Accounting Review, 87(1), 91-120.

Brian, I., \& Martani, D. (2014). Analisis Pengaruh Penghindaran Pajak dan Kepemilikan Keluarga terhadap Waktu Pengumuman Laporan Keuangan Tahunan Perusahaan. Simposium Nasional Akuntansi 17. Lombok.

Cahyadi, A., \& Sumiyana. (2013). Peran Perbedaan Laba Berbasis Nilai Buku dan Pajak dalam Menjelaskan Persistensi Laba (Studi Pada Perusahaan yang Terdaftar di Bursa Efek Indonesia). Simposium Nasional Akuntansi 16. Manado.

Creswell, J. W. (2014). Research Design Pendekatan Kualitatif, Kuantitatif, dan Mixed. Yogyakarta: Pustaka Pelajar.

Firman, A. (2013). Kualitas Laba, Corporate Government dan Tax Management. Simposium Nasional Akuntansi 16. Manado.

Fontanella, A., \& Martani, D. (2014). Pengaruh Karakeristik Perusahaan terhadap Book Tax Differences pada Perusahaan Listed di Indonesia. Simposium Nasional Akuntansi 17. Lombok.

Ghozali, I. (2009). Aplikasi Analisis Multivariate dengan Program SPSS. Semarang: BP Universitas Diponegoro.

Gujarati, D. N., \& Porter, D. C. (2013). Dasar-Dasar Ekonometrika Edisi 5 Buku 1. Jakarta: Salemba Empat. 
Halim, A., Rangga Bawono, I., \& Dara, A. (2014). Perpajakan Konsep, Aplikasi, Contoh, dan Studi Kasus. Jakarta: Salemba Empat.

Hanlon, M., \& Heitzman, S. (2010). A Review of Tax Research. Journal of Accounting and Economics, 50, 127-178.

Hart, O. (1995). Corporate Governance: Some Theory and Implications. The Economic Journal 105(430), 678-689.

Jakawinarna, \& Sutaryo. (2013). Karakteristik DPRD dan Kinerja Penyelenggaraan Pemerintah Daerah : Dukungan Empiris dan Perspektif Teori Keagenan. Simposium Nasional Akuntansi 16. Manado.

Monks, R. A., \& Minow, N. (2004). Corporate Governance. Oxford: Blackwell Publishing.

Nuritomo, \& Martani, D. (2014). Insentif Pajak, Kepemilikan dan Penghindaran Pajak Perusahaan Studi Penerapan Peraturan Pemerintah Nomor 81 Tahun 2007. Simposium Nasional Akuntansi 17. Lombok.

Oktavia, \& Martani, D. (2013). Penggunaan Derivatif Keuangan sebagai Sarana Penghindaraan Pajak. Simposium Nasional Akuntansi 16. Manado.

Pradipta, D. H., \& Surpiyadi. (2015). Pengaruh Corporate Social Responsibility, Profitabilitas, Leverage, dan Komisaris Independen terhadap Praktik Penghindaran Pajak. Simposium Nasional Akuntansi 18. Medan.

Prakosa, K. B. (2014). Pengaruh Profitabillitas, Kepemilikan Keluarga dan Corporate Governance terhadap Penghindaran Pajak di Indonesia. Simposium Nasional Akuntansi 17. Lombok.

Pramitasari, B. (2009). Analisis Book Tax Differences terhadap Persistensi Laba dan Laba Akrual sebagai Variabel Moderating Pada Perusahaan yang terdaftar di Bursa Efek Indonesia. Jurnal Akuntansi dan Investasi. 10(1), $35-45$

Purwono, H. (2010). Dasar-Dasar Perpajakan dan Akuntansi Pajak. Jakarta: Erlangga.

Resmi, S. (2009). Perpajakan Teori dan Kasus, Buku 1 Edisi 5. Jakarta: Salemba Empat.

Ridha, M., \& Martani., D. (2014). Analisis Agresivitas Pajak, Agersivitas Laporan Keuangan, Kepemilikan Keluarga dan Tata Kelola Perusahaan di Indonesia. Simposium Nasional Akuntansi 17. Lombok. 
Rusydi, M. K., \& Martani., D. (2014). Pengaruh Struktur Kepemilikan terhadap Aggresive Tax Avoidance. Simposium Nasional Akuntansi 17. Lombok.

Sari, K. D. (2013). Determinan Variasi Effective Tax Rates (Etrs) Perusahaan dan Reformasi Pajak: Studi terhadap Perusahaan yang Terdaftar di BEI Periode 2008-2009. Simposium Nasional Akuntansi 16. Manado.

Sirait, N. S., \& Martani, D. (2014). Pengaruh Perusahaan Keluarga dan Penghindaran Pajak pada Perusahaan Manufaktur di Indonesia dan Malaysia. Simposium Nasional Akuntansi 17. Lombok.

Sismi, A. L., \& Martani., D. (2014). Pengaruh Perbedaan Laba Akuntansi dengan Laba Pajak dan Kepemilikan Keluarga terhadap Persistensi Laba. Simposium Nasional Akuntansi 17. Lombok.

Tang, T., \& Firth, M. (2012). Earning Persistence and stock market reactions to the different information in Book-Tax Difference: evidence from China. The International Journal of Accounting, 47, 369-397.

Waluyo. (2012). Akuntansi Pajak Edisi 4. Jakarta: Salemba Empat.

Waluyo. (2014). Perpajakan Indonesia, Edisi 11 Buku 1. Jakarta: Salemba Empat.

Widjaja, P. H., \& Bunaidi, C. P. (2013). Analisis Pengaruh Kepemilikan Institusional, Proporsi Komisaris Inependen dan Kualitas Audit terhadap Tingkat Agresivitas Pajak serta Implikasinya terhadap Nilai Perusahaan Jangka Pendek. Simposium Nasional Akuntansi 16. Manado.

Yuniasih, d. (2013). Struktur Kepemilikan dan Tax Avoidance Perusahaan yang Terdaftar di Bursa Efek Indonesia. Simposium Nasional Akuntansi 16. Manado. 